\title{
Verba Rara Amicorum lob: The Greek rendering of Hebrew absolute hapax legomena in the speeches of Eliphaz, Bildad and Elihu in LXX job
}

\begin{tabular}{|c|c|}
\hline \multicolumn{2}{|c|}{$\begin{array}{l}\text { Author: } \\
\text { Bryan Beeckman }{ }^{1,2} \text { (D) }\end{array}$} \\
\hline \multicolumn{2}{|c|}{$\begin{array}{l}\text { Affiliations: } \\
{ }^{1} \text { Research Institute for } \\
\text { Religions, Spiritualities, } \\
\text { Cultures, Societies (RSCS), } \\
\text { Faculty of Theology, } \\
\text { UCLouvain, Louvain-la- } \\
\text { Neuve, Belgium }\end{array}$} \\
\hline \multicolumn{2}{|c|}{$\begin{array}{l}{ }^{2} \text { Biblical Studies, Faculty of } \\
\text { Theology and Religious } \\
\text { Studies, KU Leuven, } \\
\text { Leuven, Belgium }\end{array}$} \\
\hline \multicolumn{2}{|c|}{$\begin{array}{l}\text { Corresponding author: } \\
\text { Bryan Beeckman, } \\
\text { bryan.beeckman@ } \\
\text { uclouvain.be }\end{array}$} \\
\hline \multicolumn{2}{|c|}{$\begin{array}{l}\text { Dates: } \\
\text { Received: } 18 \text { Mar. } 2021 \\
\text { Accepted: } 19 \text { May } 2021 \\
\text { Published: } 17 \text { Aug. } 2021\end{array}$} \\
\hline \multicolumn{2}{|c|}{$\begin{array}{l}\text { How to cite this article: } \\
\text { Beeckman, B., 2021, 'Verba } \\
\text { Rara Amicorum lob: The } \\
\text { Greek rendering of Hebrew } \\
\text { absolute hapax legomena in } \\
\text { the speeches of Eliphaz, } \\
\text { Bildad and Elihu in LXX job', } \\
\text { HTS Teologiese Studies/ } \\
\text { Theological Studies } \\
\text { 77(1), a6632. https://doi. } \\
\text { org/10.4102/hts.v77i1.6632 }\end{array}$} \\
\hline \multicolumn{2}{|c|}{$\begin{array}{l}\text { Copyright: } \\
\text { (C) 2021. The Authors. } \\
\text { Licensee: AOSIS. This work } \\
\text { is licensed under the } \\
\text { Creative Commons } \\
\text { Attribution License. }\end{array}$} \\
\hline \multicolumn{2}{|c|}{ Read online: } \\
\hline 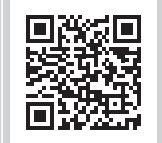 & $\begin{array}{l}\text { Scan this QR } \\
\text { code with your } \\
\text { smart phone or } \\
\text { mobile device } \\
\text { to read online. }\end{array}$ \\
\hline
\end{tabular}

In 2011, Elke Verbeke has examined the Greek rendering of Hebrew absolute and non-absolute hapax legomena in the Septuagint (LXX) version of Job. This examination has indicated that the LXX translator of Job dealt with hapaxes in a variety of ways, that is, omission, transliteration, consistent rendering, association with a similar-looking word, contextual exegesis, approximate translation and paraphrasing. Although Verbeke's study has shed more light on the translation technique of the LXX translator of Job, she has only examined the Hebrew hapaxes and their Greek rendering in the speeches of Job and God. In order to come to a more accurate description of the translation technique of LXX Job, this article has analysed the Greek rendering of Hebrew absolute hapax legomena in the speeches of Job's friends. This examination has indicated that the LXX translator of Job has applied a diversity of techniques to deal with Hebrew hapaxes. Therefore, this article has obtained a more complete image of the translation technique of LXX Job.

Contribution: This article fits well within the scope of HTS Teologiese Studies/Theological Studies because it focusses on the translation technique of the LXX translator of Job and thus contributes to research regarding historical thought (textual transmission of biblical texts) and sourceinterpretation (because the LXX translator does not only reflect a translational but also an interpretative process).

Keywords: LXX; Septuagint; job; hapax legomena; translation technique; absolute hapax legomena; hapaxes.

\section{Introduction}

From 2006 onwards, a new approach to study the translation technique of the different Septuagint (LXX) books has been developed in Leuven by Bénédicte Lemmelijn and Hans Ausloos: the content- and context-related approach (Ausloos \& Lemmelijn 2010). This approach takes content- and context-related criteria, such as Hebrew hapax legomena (Ausloos 2009; Ausloos \& Lemmelijn 2008, 2012; Lemmelijn 2014; Verbeke 2008), Hebrew wordplay (Ausloos, Lemmelijn \& Kabergs 2012; Kabergs \& Ausloos 2012) and Hebrew jargon-defined vocabulary (Beeckman 2019, 2020; Lemmelijn 2008), as a starting point. As these semantic and stylistic situations might have posed difficulties for the LXX translators (Lemmelijn 2014:137), the analysis of these criteria and their Greek rendering in the LXX can shed more light on the different translation techniques.

Within the framework of this approach, several studies on the Greek rendering of Hebrew hapax legomena have been conducted (see supra). One of the more elaborate attempts is the (unpublished) doctoral dissertation of Elke Verbeke. In this work, Verbeke has analysed the Greek rendering of Hebrew absolute and non-absolute hapax legomena in Job. This examination has indicated that the LXX translator of Job dealt with hapaxes in a variety of ways, that is, by omission, transliteration, consistent rendering, association with a similar-looking word, contextual exegesis, approximate translation and paraphrasing (Verbeke 2011:369-416). However, she has only examined the hapax legomena and their Greek rendering in the dialogues between God and Job. Although the results of her analysis can be considered as an important contribution to the characterisation of the translation technique of LXX Job, an examination of the remaining hapax legomena in Job is necessary in order to obtain a more complete understanding of the translation technique of the LXX translator. Therefore, this article will analyse the Greek rendering of Hebrew absolute hapax legomena in the speeches of Job's friends, more specifically, those of Eliphaz, Bildad and Elihu. In the speech of Zophar, in chapter 11, only one hapax is found:

1.Verbeke (2011:115) recorded another hapax in her list, that is, עוף (Job 11:17). However, because it is only recorded as a hapax in Lisowsky's work, it cannot be considered a hapax legomenon. See rules-of-thumb infra. 
study we are only interested in absolute hapax legomena, as they have been called by Immanuel Casanowicz, who made a distinction between absolute and non-absolute hapaxes. Absolute hapax legomena are words that are derived from any other existing Hebrew lexeme. This is in contrast to nonabsolute hapax legomena that can be linked to an existing Hebrew lexeme. The hapax in the speech of Zophar cannot be considered as an absolute, but rather as a non-absolute hapax legomenon, as it is also recorded as such by Lisowsky and Greenspahn and not mentioned in Casanowicz's list (Verbeke 2011:115). Therefore, this hapax will not be discussed here. What will be discussed is the following.

Firstly, all the absolute Hebrew hapax legomena and their Greek rendering in the speeches of Eliphaz, Bildad and Elihu will be registered. Afterwards, these lexemes will be examined in order to discern whether the Greek rendering is because of the translation technique of the LXX translator, or rather to a different Hebrew Vorlage or to textual transmission of the Greek text. This way, this contribution aims at providing a more detailed description of the translation technique of LXX Job.

\section{The registration of Hebrew absolute hapax legomena and their Greek rendering in the speeches of Eliphaz, Bildad and Elihu}

Before registering the absolute Hebrew hapax legomena in the speeches of Eliphaz, Bildad and Elihu, it is necessary to indicate what we understand by the term 'absolute hapax legomena'. Derived from the Greek $\alpha$ $\pi \alpha \xi$ $\lambda \varepsilon \gamma o ́ \mu \varepsilon v \alpha$, hapax legomena are words that only occur once in a given corpus. Within the framework of this study, that takes the content- and context-related approach as a methodological approach, the corpus in question is the whole Hebrew Bible. Moreover, as already indicated in the introduction, this study examines the Greek rendering of Hebrew absolute hapax legomena.

Verbeke has made a list containing all the absolute and non-absolute Hebrew hapax legomena in the Hebrew Bible. This list is based upon four resources: BibleWorks, the works of Greenspahn (1984), Casanowicz (1904) and Lisowsky (1958). Next to an exhaustive list of hapaxes in the Hebrew Bible, Verbeke's list provides the reader with an overview on whether a hapax is labelled as an absolute or non-absolute hapax by a certain author (this distinction is not found in BibleWorks). As not every author agrees on whether a certain hapax is absolute or non-absolute, the following rules-of-thumb will be taken into consideration to determine whether a hapax is absolute or not.

\section{Rule-of-thumb I: To discern whether a word is a hapax or not}

1. The words that have been labelled as a hapax by one author and BibleWorks or by two, three or all of the authors and/or BibleWorks can be regarded as a hapax (absolute or non-absolute)

2. Those that are only labelled as a hapax legomenon by only one author or by BibleWorks cannot be regarded as a hapax.

\section{Rule-of-thumb II: To discern whether a hapax is absolute or non-absolute}

1. If all three authors agree on whether a certain hapax is absolute, we can record it as such. For example, (4:10) $\Rightarrow \mathrm{a}($ Lis, Cas, Gr) $\Rightarrow \mathrm{a}$

2. If two of the three authors agree on whether a certain hapax is absolute, we can record it as such. For example, (15:24) $\Rightarrow$ a (Lis, Cas) + na (Gr) $\Rightarrow$ a

3. If the hapax legomenon is only attested by two of the three authors and they do not agree on whether the hapax is absolute or non-absolute, then the decision will be made in favour of Greenspahn being the younger one and incorporating and interpreting the earlier views on hapax legomena. For example, קים (22:20) $\Rightarrow$ na (Lis) + a $(\mathrm{Gr}) \Rightarrow \mathrm{a}$

4. If the hapax is only recorded by one of the authors and BibleWorks, the decision will be made in favour of this one author because BibleWorks does not make the distinction between absolute and non-absolute. For example, אהל (25:5) $\Rightarrow$ a (Cas) $\Rightarrow$ a.

Following Verbeke's list and the rules-of-thumb I have formulated supra, we arrive at 15 absolute hapax legomena in the speeches of Eliphaz, Bildad and Elihu. ${ }^{2}$

TABLE 1: Hebrew absolute hapax legomena in the speeches of Eliphaz, Bildad and Elihu and their Greek rendering in the LXX.

\begin{tabular}{|c|c|c|c|}
\hline Verse & MT & LXX & DSS \\
\hline $4: 10$ & 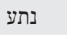 & $\sigma \beta \varepsilon ́ v v u \mu t$ & / \\
\hline $4: 18$ & 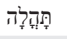 & 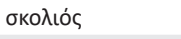 & lacuna (4QtgJob [4Q157]) \\
\hline $15: 12$ & 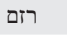 & 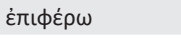 & / \\
\hline $15: 24$ & בכידידוֹר & $\pi i \pi \tau \omega$ & / \\
\hline $15: 27$ & פִִּימָה & 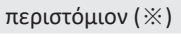 & / \\
\hline $15: 29$ & מִנְלְלה & бкĹ⿱㇒冋 & / \\
\hline $18: 2$ & 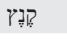 & 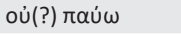 & סוף (11QtgJob) \\
\hline 18:3 & 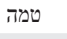 & $\sigma \iota \omega \pi \alpha \dot{\omega}$ & דמינא (11QtgJob) \\
\hline 22:20 & 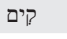 & ن்то́бтабıৎ (※) & lacuna (11QtgJob) \\
\hline 25:5 & 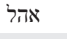 & 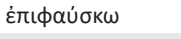 & זכי (11QtgJob) \\
\hline $33: 20$ & 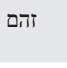 & 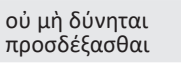 & l \\
\hline $33: 24$ & 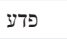 & / & פצהי (11QtgJob)/lacuna (4QJoba [4Q99]) \\
\hline $33: 25$ & רטפש & $\dot{\alpha} \pi \alpha \lambda u ́ v \omega$ & בשרו (4QJoba [4Q99])/lacuna (11QtgJob) \\
\hline $35: 15$ & שפָּ & $\pi \alpha \rho \alpha ́ \pi \tau \omega \mu \alpha(※)$ & lacuna (11QtgJob) \\
\hline $37: 16$ & מִפְְלְש & 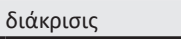 & להלבש\}\{11QtgJob) \\
\hline
\end{tabular}

However, as we are only interested in the translation technique of the Old Greek (OG) translator of Job, the passages marked with an asterisk (※) in Ziegler's critical edition (Ziegler 1982)

2.As the Biblia Hebraica Quinta of Job, which is being prepared by Robert Althann, is forthcoming in 2021, MT is based upon the Biblia Hebraica Stutgartensia: (Elliger \& Rudolph ${ }^{5}$ 1977). For the LXX-version, the Septuagint text the Göttingen edition is used (Ziegler 1982). For the Dead Sea Scrolls (DSS), the book of Job is attested in 20 Job, 4QPaleo Jobc 4Q J $^{\text {a }}$ and 4O Job ${ }^{\text {b }}$ (eds. Baillet, Milik \& De Vaux 1962:71. eds. Skehan, Ulrich \& Sanderson 1992:155-157; eds. Ulrich et al 2000:171-180). A Skehan, Ulrich \& Sanderson 1922:155-157; eds. Ulrich et al. 2000:171-180). A Targum version of Job (110tgob) (eds. Van der Ploeg \& Van der Woude 1971; eds. García Martínez et al. 1998:79-180) and some fragments (4QtgJob) have also been found (Milik 1977:90; see also Puech 2020). 
will not be discussed. ${ }^{3}$ Three verses containing a Hebrew absolute hapax legomena (Table 1) have a Greek counterpart that pertains to the asterisk material, that is, 15:27 (פָָּ), 22:20 (קים) and 35:15 (שפ). This leaves us with 12 absolute hapax legomena that will be evaluated in the next paragraph.

\section{The evaluation of Hebrew absolute hapax legomena and their Greek rendering in the speeches of Eliphaz, Bildad and Elihu}

Now that we have registered all the Hebrew absolute hapax legomena in the speeches of Eliphaz, Bildad and Elihu, we will evaluate them. In order to do so, we need to discern whether the rendering in the LXX is because of the translator's activity, to a diverging Hebrew Vorlage or to a later redaction during the process of the textual transmission of the Greek text.

Before we start the evaluation, one final methodological remark should be made. As the study of hapax legomena concerns the field of lexicography, multiple Hebrew and Greek lexica have been consulted. ${ }^{4}$ Nevertheless, one must keep in mind that the meaning ascribed to hapax legomena in lexica has often been influenced by different ancient translations of the Hebrew Bible such as the LXX itself (Ausloos 2013:294, 300; Muraoka 1991:212). As the meaning of Hebrew hapaxes is obscure and in many instances at least uncertain, lexicographers tend to look at the LXX translation in order to detract from their meaning. However, in the case of absolute hapaxes, although their meaning cannot be derived from an existing Hebrew root, scholars have often pointed at their affiliation with cognate languages such as Aramaic, Arabic and Syriac. If this is the case, their meaning can often be derived from these languages (as will be clear infra). Be that as it may be, in this study, we are not interested in hapax legomena as such, but rather, and in view of a more accurate characterisation of the translation technique of LXX Job, only in the way in which the LXX translator has dealt with them because they most probably have presented a difficult semantic situation (Ausloos 2013:326; Lemmelijn 2014:137; Verbeke 2011:lxii).

\section{Job 4:10 (נתע)}

MT

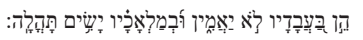

The roar of the lion, the voice of the fierce lion and the teeth of the young lions are broken. 5
LXX

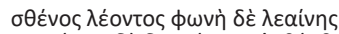

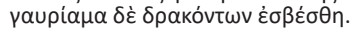

The strength of the lion and the voice of the lioness and the pride of dragons were extinguished. ${ }^{6}$
3.In Ziegler's text, there are some verses that belong to the asterisked material, which are left unmarked. Therefore, Gentry (1995:31) has provided an updated list of the asterisked material in LXX Job. The list of Gentry is taken as a point of departure to discern the asterisked material in LXX Job for this study.

4.For the English translation of the Hebrew and Greek lexemes, several lexicons and dictionaries have been consulted. For the Hebrew words: Genesius (1921),
Brown-Driver-Briggs (BDB) (1979), Clines (1993-2016) and Koehler and Baumgartner (1953). For the Greek words: Lust, Eynikel and Hauspie (LEH) (2015) Muraoka (2009), Liddell, Scott and Jones (1996:online) and Montanari (2015).

5.English translation of Hebrew text taken from NRSV.

6.English translation of the LXX taken from NETS. The LXX version of Job has been translated by Cox (2007:667-696).
The LXX presents a different reading than MT in this verse. The rendering of כִִִּיר by $\delta \rho \alpha ́ \kappa \omega v$ is noteworthy. However, what is of interest here, is the rendering of the Hebrew hapax

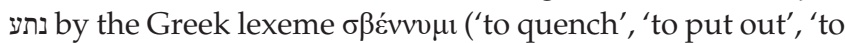
extinguish'). Scholars agree that נתע is an Aramaic form of the verb נתץ ('to tear down', 'to break up', 'to demolish') (BDB 1979:683; Beer 1897:47; Seow 2013:397). Choon-Leong Seow classifies it amongst the Hebrew lexemes that have a root starting with נת, indicating 'elimination or removal' (Seow 2013:397). Therefore, the LXX's rendering of $\sigma \beta \varepsilon \dot{v} v v v \mu$, also denoting elimination or extinguishing, seems to be an adequate rendering. ${ }^{7}$ This lexeme is used throughout LXX Job to translate different Hebrew lexemes, that is, עלל (16:15), דעך (18:5, 18:6, 21:17), נכפק (30:8), כנע (19:12) בעל (19:12). According to Ziegler (1934:284), $\sigma \beta \varepsilon \dot{v v v u \mu t ~ i s ~ a ~ f a v o u r i t e ~}$ lexeme of LXX Job to render obscure or difficult Hebrew lexemes (see also Verbeke 2011:254). However, in this case, it seems that the LXX translator has understood the general meaning of the Hebrew hapax.

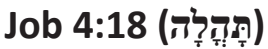

\begin{tabular}{|c|c|c|}
\hline MT & LXX & 4QtgJob \\
\hline 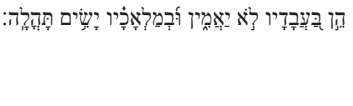 & 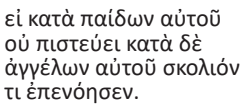 & ובמלאכו[הי ישים \\
\hline $\begin{array}{l}\text { Even in his servants he puts no } \\
\text { trust, and he charges his angels } \\
\text { with error. }\end{array}$ & $\begin{array}{l}\text { Whether he believes } \\
\text { charges against his } \\
\text { servants, who know, } \\
\text { but he took note of any } \\
\text { crookedness in his } \\
\text { angels. }\end{array}$ & $\begin{array}{l}\text { and against } \\
\text { [his] angels } \\
\text { [he] charges }\end{array}$ \\
\hline
\end{tabular}

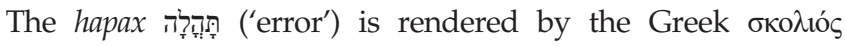
('crooked') in this verse. It is not preserved in 4QtgJob. Several scholars think that the hapax stems from the root ('be foolish') (Beer 1897:27; Dhorme 1967:53). ${ }^{9}$ Apparently, Symmachus ( $\left.\sigma^{\prime}\right)$ has understood it this way and rendered it by $\mu \alpha \tau \alpha$ ió $\eta \tau \alpha$

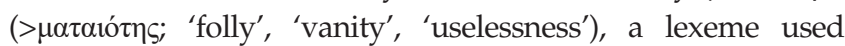
abundantly in both LXX Psalms and Ecclesiastes and once in Proverbs. If those scholars are correct, then must be regarded as a non-absolute hapax legomenon instead of an absolute hapax although Greenspahn, Casanowicz and Lisowsky all agree that it is an absolute hapax (Verbeke 2011:114).

When the hapax can be understood as a derivative from the root הלל, the rendering of $\sigma^{\prime}$ reflects a more adequate

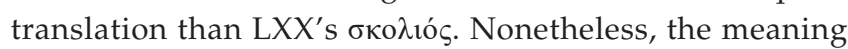
of $\sigma \kappa o \lambda$ tós pertains to the same semantic field as הלל, because crookedness can be considered a consequence of folly (Cox, forthcoming).${ }^{10}$ Moreover, the LXX translator has rendered the second colon of this verse rather literally,

7.The term 'adequate rendering' used in this article denotes a (literal) rendering whereby the Hebrew word has been rendered with a corresponding Greek equivalent that shares the same meaning as the Hebrew.

8.Translated from the French translation of Puech (2020:138). Florentino García Martínez and Eibert Tigchelaar translate it differently: 'and with $\mathrm{h}[\mathrm{is}]$ angels [...]' (García Martínez \& Tigchelaar 2000:305).

9.The root הלל entails multiple meanings. The most commonly known is 'to sing, to praise, to shout exultingly' but it can also mean 'to act like a madman, folly' and 'to begin to shine' (see Job 25:5 infra) (Koehler \& Baumgartner 1953:235-236).

10.I would like to express my gratitude to Claude E. Cox for giving me access to his unpublished manuscript of his SBL commentary on LXX Job. 
providing a Greek equivalent for each Hebrew lexeme and thus more or less quantitatively representing the Hebrew:

\begin{tabular}{|c|c|}
\hline 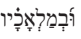 & 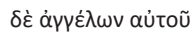 \\
\hline רִיְֶׁים & 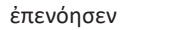 \\
\hline 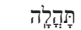 & 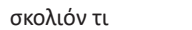 \\
\hline
\end{tabular}

The addition of the indefinite neutral pronoun $\tau$ ' ('any')

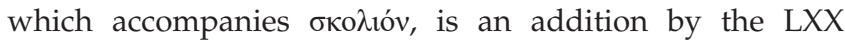
translator to emphasise that no single error or any crooked ways of God's angels are left unnoticed. By doing so, the LXX translation seems to stress the omniscience of God. ${ }^{11}$

\section{Job 15:12 (רז)}

\begin{tabular}{|c|c|}
\hline MT & LXX \\
\hline 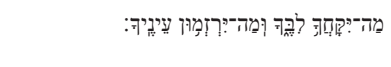 & 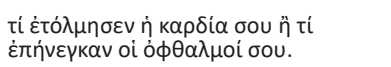 \\
\hline $\begin{array}{l}\text { Why does your heart carry you away, } \\
\text { and why do your eyes flash. }\end{array}$ & $\begin{array}{l}\text { What did your heart dare, or what did } \\
\text { your eyes set themselves upon. }\end{array}$ \\
\hline
\end{tabular}

The LXX represents the Hebrew quantitatively in this verse. The Hebrew hapax רזם ('to wink') is rendered here by

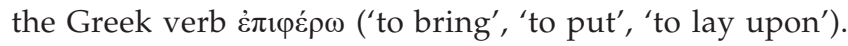
The verb רזם has possibly been derived from the Aramaic verb רמז ('to indicate [through a physical motion]', 'signal', 'to wink') (BDB 1979:931). Dhorme (1967:212-213) had postulated the retroversion ירומון as being the Hebrew Vorlage of the LXX. However, Seow (2013:714) argues that this retroversion is difficult to explain when taking all the manuscript evidence into account. He thinks that the LXX translator understood the Hebrew as 'to stare' (cognate to the Arabic razama) (Seow 2013:714). Thus, given Seow's argumentation and considering the LXX translator's quantitative representation in this verse, it is reasonable to assume that the LXX translator has rendered the Hebrew hapax with a corresponding Greek equivalent, that is, $\dot{\varepsilon} \pi \imath \varphi \varepsilon ́ \rho \omega$.

\section{Job 15:24 (כִידוֹר)}

\begin{tabular}{|c|c|}
\hline MT & LXX \\
\hline 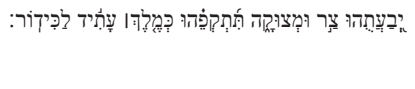 & 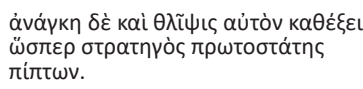 \\
\hline $\begin{array}{l}\text { Distress and anguish terrify them; they } \\
\text { prevail against them, like a king } \\
\text { prepared for battle. }\end{array}$ & $\begin{array}{l}\text { And distress and anguish will take } \\
\text { hold of him; he will be like a } \\
\text { general falling in the front rank. }\end{array}$ \\
\hline
\end{tabular}

So far, no one has given a well argumented answer to the question why the translator has opted for $\pi i \pi \tau \omega$ as a rendering of כִידוֹ. The hapax might have an affiliation with the Syriac ( $k d r$, 'to disturb'), Akkadian (kadāru, 'to be overbearing, arrogant, spirited'; kadru, 'aggressive'; kadrūtu, 'aggressiveness') or Arabic (kadara, 'to throw down, to disturb, afflict, distress') (Seow 2013:719). Therefore, Seow concludes that the term 'should probably be understood to mean "aggression, attack, combat"' (Seow 2013:719; see also BDB 1979:461; Clines 1998:391). Claude E. Cox argues that the LXX translator 11.That the LXX translator of Job made some theological nuances with respect
to the figure of God is also observed by Johann Cook (Cook \& Van der Kooij to the figure of
2012:182-183). has interpreted the hapax in the same line of thought as the (Rabbinic) Targum's interpretation, that is, 'for battle', 'to die in battle' (Cox forthcoming). ${ }^{12}$

In MT, distress and anguish are the subject of this verse. They are the ones that prevail against the wicked or impious such as a king ready for battle. However, in contrast to MT, the subject of the verse in the LXX remains the impious as introduced at the beginning of the cluster (15:20). Thus, although the LXX renders the verse differently and perhaps even struggled to translate the hapax, it seems that he has opted for a rendering that was fitting with the context of the verse. This kind of contextual rendering is a technique favoured by the LXX translator to render Hebrew hapax legomena, as has been demonstrated by Verbeke in her dissertation (Verbeke 2011:390-394).

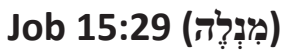

\begin{tabular}{|c|c|}
\hline MT & LXX \\
\hline 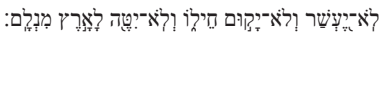 & 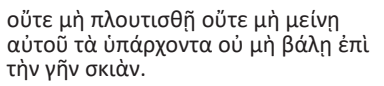 \\
\hline $\begin{array}{l}\text { They will not be rich, and their wealth } \\
\text { will not endure, nor will they strike } \\
\text { root in the earth. }\end{array}$ & $\begin{array}{l}\text { Neither shall he ever become rich, nor } \\
\text { shall his possessions last. He shall not } \\
\text { cast a shadow upon the ground. }\end{array}$ \\
\hline
\end{tabular}

The LXX renders the hapax מִנְלֶָ by the Greek noun okió. According to Seow, מִנְֶל either means 'possession' or 'root' (Seow 2013:722-723). Within the context of the verse in which there is an emphasis on plant metaphors (see e.g. De Joode 2018:101-102), the translation of 'roots' seems to make more sense. Looking at the LXX, one might think that the metaphorical language pertaining to plants in the Hebrew text of 15:28-35 has not been preserved in the LXX verse under discussion. However, the LXX does preserve the metaphor, because a tree can cast a shadow upon the ground (this has been interpreted as such by Olypiodorus [Diaconus] in his Commentarii in Job [see Hagedorn \& Hagedorn 1984:142-143]). Gerleman (1946:38-39) asserted that the translator has been influenced by the ancient tradition that the dead do not cast any shadow, which is attested in the writings of Plutarch.

Moreover, it seems that the LXX translator has tried to fit this verse into the context of the first colon of the next verse (15:30) which reads:

MT LXX

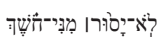

They will not escape from darkness.

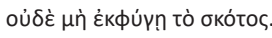
Nor shall he escape darkness.

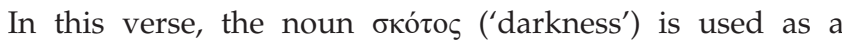

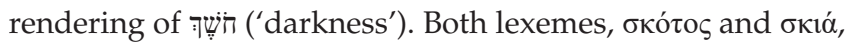
pertain to the same semantic domain and are even orthographically closely linked to one another. Moreover,

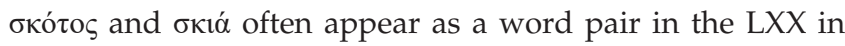
general (e.g. LXX Ps 106:10, Ps 106:14, Ob 9:79, Jr 13:16) and even occur three times in LXX Job $(3: 5,12,22 ; 28: 3)$. Thus, the choice to render the obscure word מִנְלֶָ by the Greek 12.The Aramaic reads: 'Distress and anguish terrify him; they surround him like a king
who is ready for the bier'. Some variants read '... like one who is ready to be who is ready for the bier'. Some variants read '... like one who
surrounded by legions' (Mangan 1991:47). Original italicisation. 


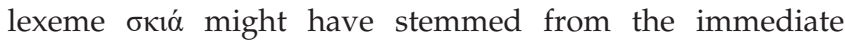
context of 15:29, that is, 15:30, in order to create the word

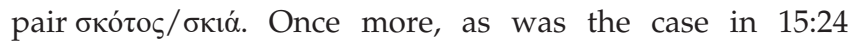
supra, the Hebrew hapax has been rendered by means of contextual exegesis. This has been generally overlooked by commentators.

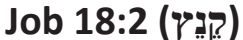

\begin{tabular}{|c|c|c|}
\hline MT & LXX & 11QtgJob \\
\hline 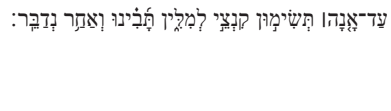 & 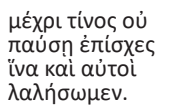 & עד אמת]י תשוא סוף למלא] \\
\hline $\begin{array}{l}\text { How long will you hunt for words? } \\
\text { Consider, and then we shall speak. }\end{array}$ & $\begin{array}{l}\text { How long before } \\
\text { you stop? Hold } \\
\text { back, so that we } \\
\text { too can speak. }\end{array}$ & $\begin{array}{l}\text { [Whe]n will you stop } \\
\text { speaking? [ }\end{array}$ \\
\hline
\end{tabular}

The hapax under discussion is offered different translations for this word, for example, 'fetters', 'bonds', 'shackles' (Dhorme 1967:257), 'traps', 'snares' (Schultens 1737:435 [Lat. laqueus]; BDB 1979:890) and 'end' (Koehler \& Baumgartner 1953:846; Seow 2013:779, see 779-780 for a full discussion). 11QtgJob has ('stop')

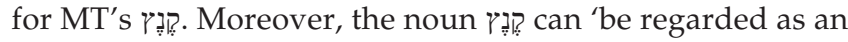

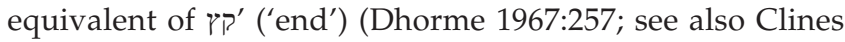
2010:271; Koehler \& Baumgartner 1953:844). Taking this into account, it is highly plausible that the hapax indeed means 'end' or 'stop'.

The editors of DJD XXIII (eds. García Martínez et al. 1998:91)

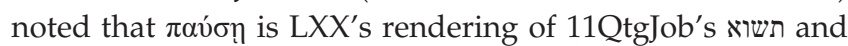

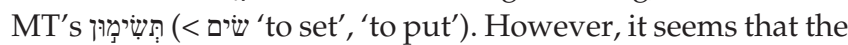

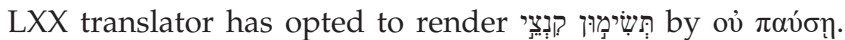
The translation of the first stich in Greek reads (literally): 'How long will you not stop?', a question from Bildad following the extensive speech of Job, requesting him to stop speaking so that Job's friends can say something as well. It is משים

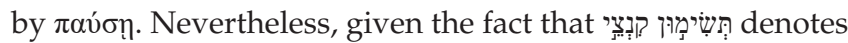
'to put a stop', the translator's choice to render it with $\pi \alpha$ w $\omega$ ('to stop') offers a very adequate rendering.

\section{Job 18:3 (טמה )}

\begin{tabular}{|c|c|c|}
\hline MT & LXX & 11QtgJob \\
\hline 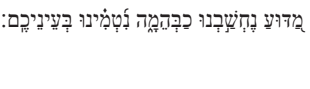 & 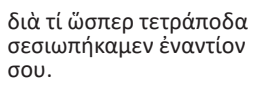 & לב]עירא דמינא] \\
\hline $\begin{array}{l}\text { Why are we counted as cattle? } \\
\text { Why are we stupid in your } \\
\text { sight? }\end{array}$ & $\begin{array}{l}\text { Why have we, like } \\
\text { quadrupeds, been silent } \\
\text { before you? }\end{array}$ & $\begin{array}{l}\text { [] do we resemble } \\
\text { [ca]ttle? [ }\end{array}$ \\
\hline
\end{tabular}

In Job 18:3, the Greek $\sigma 1 \omega \pi \alpha$ ' $\omega$ ('to be silent') for the Hebrew טמה ('to be unclean') of MT can be explained on the basis of the fragmentary attestation of this verse in 11QtgJob. 11QtgJob attests דמינא, which reflects a form of the verb דמה ('to resemble') (eds. García Martínez et al. 1998:91). Next to the meaning 'to resemble, to be like', the verb דמה can also denote 'be silent, still' (BDB 1979:199; Koehler \& Baumgartner 1953:213). Moreover, the LXX translator of Job uses oi $\omega \pi \alpha \omega$ in 29:21 and 30:27 to render the Hebrew דמם, which is a parallel form of דמה (Koehler \& Baumgartner 1953:213). Given the
11QtgJob fragment, the Hebrew Vorlage of the LXX probably had a reading that preserved a form of whereby the LXX translator interpreted as denoting 'be silent, still'.

Thus, it seems that the LXX translator offers an adequate rendering of the Hebrew verb that was attested in his Vorlage, that is, דמה, which is attested in MT as טמה. How this specific reading of MT came about reaches beyond the scope of this article, because we are solely interested in the LXX translator's attitude towards his parent text.

\section{Job 25:5 (אהל)}

\begin{tabular}{|c|c|c|}
\hline MT & LXX & 11QtgJob \\
\hline 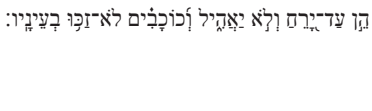 & 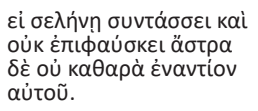 & ] זכי וכוכביא לא] \\
\hline $\begin{array}{l}\text { If even the moon is not bright and } \\
\text { the stars are not pure in his sight. }\end{array}$ & $\begin{array}{l}\text { If he instructs the } \\
\text { moon, then it does not } \\
\text { shine, and the stars are } \\
\text { not pure before him. }\end{array}$ & $\begin{array}{l}\text { [] pure, and } \\
\text { the stars are } \\
\text { not [ }\end{array}$ \\
\hline
\end{tabular}

The Hebrew hapax אהל 25:5 in to be understood as a derivative of the Hebrew root הלל ('to shine') (BDB 1979:14; Clines 1993:142; Dhorme 1967:369). Just as in Job 31:26 and

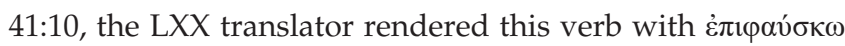
('to shine'), which only occurs in the LXX of Job (in the NT, it is only used once, namely in Eph 5:14), thus providing an adequate translation. Because this hapax might be linked to an existing Hebrew root, we cannot label it as an absolute hapax legomenon (as is the case in 4:18 supra). ${ }^{13}$

\section{Job 33:20 (בהז)}

\begin{tabular}{|c|c|}
\hline MT & LXX \\
\hline 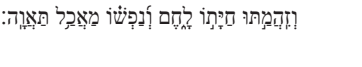 & 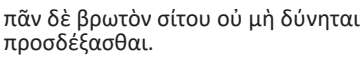 \\
\hline $\begin{array}{l}\text { So that their lives loathe bread, and } \\
\text { their appetites dainty food. }\end{array}$ & $\begin{array}{l}\text { And he shall not be able to take any } \\
\text { edible bit of food. }\end{array}$ \\
\hline
\end{tabular}

The LXX only attests the first stich of verse 33:20. Stich $b$, that

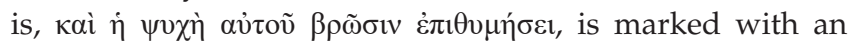
asterisk and is not part of OG.

The Greek text of the LXX offers a completely different translation of the Hebrew text attested in MT. Concerning the hapax under examination, that is, זהם (which means 'be foul, loathsome', from the Aramaic זהים 'foul' [BDB 1979:263]), Dhorme (1967:498) and Beer (1897:211) argued that the

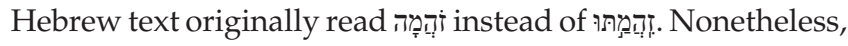
the LXX rendering does not provide an exact quantitative representation of the Hebrew of $\mathrm{MT}$, but rather a paraphrastic one because the hapax in 33:20 is represented by the phrase ov̉ $\mu$ 门̀ $\delta \dot{v} \eta \tau \alpha l \pi \rho \sigma \delta \delta \varepsilon \xi \alpha \sigma \theta \alpha$ l (he will not be able to take or receive). If the translator paraphrased the Hebrew, he understood the hapax as 'something that cannot be eaten'. The negative connotation of זהם is thereby represented by the construction ov̉ $\mu$ ì. However, it 13.The authors who worked on the registration of hapaxes in the Hebrew Bible do not
agree whether is a hapax or not. Only BibleWorks and Casanowicz label it as such (the latter labels it as an absolute hapax) (Verbeke 2011:117). 
is hard to tell whether the LXX translator has provided a paraphrastic rendering of his Hebrew Vorlage, which might have resembled MT or whether his Vorlage has actually differed from MT.

\section{Job 33:24 (פדצ)}

\begin{tabular}{|c|c|c|c|}
\hline MT & LXX & 11QtgJob & 4QJob ${ }^{\mathrm{a}}$ \\
\hline 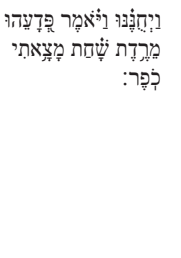 & 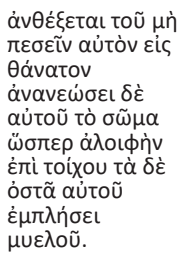 & 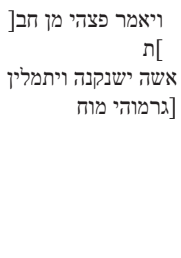 & 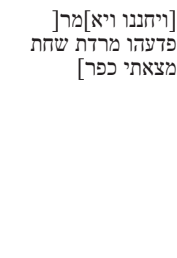 \\
\hline $\begin{array}{l}\text { And he is } \\
\text { gracious to that } \\
\text { person, and } \\
\text { says, 'Deliver him } \\
\text { from going down } \\
\text { into the Pit; I } \\
\text { have found a } \\
\text { ransom.' }\end{array}$ & $\begin{array}{l}\text { He will provide } \\
\text { support so that } \\
\text { he does not fall } \\
\text { into death and } \\
\text { renew his body } \\
\text { like paint does a } \\
\text { wall and fill his } \\
\text { bones with } \\
\text { marrow.' }\end{array}$ & $\begin{array}{l}\text { And he will say: } \\
\text { 'Save him from } \\
\text { ha[rm] of fire } \\
\text { strangles him. } \\
\text { And [his bones] } \\
\text { will be filled } \\
\text { [with marrow.]' }\end{array}$ & $\begin{array}{l}\text { And he is } \\
\text { gracious to that } \\
\text { person, and says, } \\
\text { 'Deliver him } \\
\text { from going down } \\
\text { into the Pit; I } \\
\text { have found a } \\
\text { ransom.' }\end{array}$ \\
\hline
\end{tabular}

According to Seow (2011:168), the Hebrew hapax פדע should be read as פרע ('to loose', 'to free', and also possibly 'ransom'), because this is attested in MSS ${ }^{\operatorname{kenn} 206,454}$ and because the dalet and reš were 'graphically similar [...] in the paleo-Hebrew script'. The hapax is attested in MT; in 4QJob there is a lacuna. 11QtgJob, on the other hand, records פצהי which means 'to deliver', 'to save'. ${ }^{14}$ According to the editors of DJD, this reading is based upon the reading of MT's פדעהו פדהו (eds. García Martínez et al. 1998:132; see also Heater 1982:105).

The LXX provides a completely different reading from MT. One might think that the translator has elaborated this verse, because the Hebrew text is considerably shorter than the Greek one. However, the suggestion of the editors of DJD that 11QtgJob probably lacks two hemistichs that are missing in MT, implies that it might have reflected the Hebrew Vorlage of the LXX translator (eds. García Martínez et al. 1998:132). Even if this is the case, the LXX does not provide a rendering for פדעהו (MT) or פדהו (11 QtgJob). ${ }^{15}$ In this verse, it seems that the LXX translator has ignored the hapax (perhaps because he did not know its meaning). Instead, he has elaborated on the negative image of flesh and bones that is introduced in 33:21 and contrasted it with a positive image in 33:24b:

33:21 (LXX)

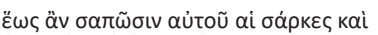

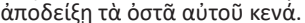

Until his flesh rots and he shows his bones to be bare.

This contrasting elaboration of the image of the renewed body and bones is absent in MT's version of 33:24.

\section{Clines (2007:655) and BDB (1979:804) translated פדע with 'deliver'.}

15.Contrary to Homer Heater, who believes it has been rendered in the LXX (Heater 1982:105). However, he does not indicate the Greek equivalent of the Hebrew hapax.
Job 33:25 (רטפטש)

\begin{tabular}{|c|c|c|c|}
\hline MT & LXX & 11QtgJob & 4QJob ${ }^{\mathrm{a}}$ \\
\hline 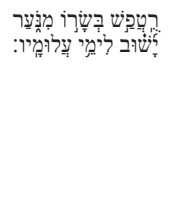 & 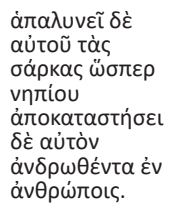 & עולים & ישוב לימי עלומין] \\
\hline $\begin{array}{l}\text { Let his flesh } \\
\text { become fresh } \\
\text { with youth; let } \\
\text { him return to the } \\
\text { days of his } \\
\text { youthful vigour. }\end{array}$ & $\begin{array}{l}\text { And will make his } \\
\text { flesh soft like an } \\
\text { infant's and } \\
\text { restore him } \\
\text { full-grown } \\
\text { amongst people. }\end{array}$ & $\begin{array}{l}\text { ] than that of a } \\
\text { youth, and he } \\
\text { will return to the } \\
\text { days of [his] } \\
\text { you[th. }\end{array}$ & $\begin{array}{l}\text { [ ] his flesh } \\
\text { become fresh } \\
\text { with youth; [let } \\
\text { him return to the } \\
\text { days of his } \\
\text { youthful vigour.] }\end{array}$ \\
\hline
\end{tabular}

In $4 \mathrm{QJob}^{\mathrm{a}}$, the last letters of the first word are attested, although they are barely readable. The editors of DJD XVI suggest that it cannot be a šin, but rather a reš-waw construction (eds. Ulrich et al. 2000:174). Thus, 4QJob a probably had a different reading for MT's רְּר: However, because the complete word is not attested, it is hard to discern what the word might have been. It might as well be a dittography of בשרו.

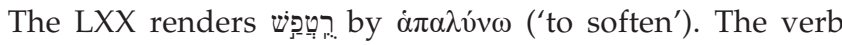
$\dot{\alpha} \pi \alpha \lambda v v \omega$ only occurs three times in the LXX, that is, 2 Kings 22:19, Psalms LXX 54:22 and Job 33:25, as a rendering of the Hebrew verb רכך ('to be tender'). Seow (2011:169-170) argues that it is possible that the reš is a dittograph and that the root is ('be unsensible', 'unfeeling' and often also translated by 'be fat') (see also BDB 1979:936), which also occurs in Ps 119:70 (LXX 118:70) (see also Dhorme 1967:503 and especially Altschüller 1886:212 who introduced this idea). However, one might argue that the fragmentary $4 \mathrm{QJob}^{\mathrm{a}}$ attests khaf-waw and that the Vorlage of the LXX translator recorded רכו as is the case in Ps 55:22 (MT). When looking at the fragment (i.e. plate 1116, fragment 5) itself, one can detect a little dot of ink under the waw that might reflect the presence of a khaf, certainly when compared with other khafs by the scribe's hand (see e.g. Job 32:4 in 4QJoba). Thus, the LXX's Vorlage might have attested רכך and consequently, the LXX translator provided an adequate rendering (i.e. $\dot{\alpha} \pi \alpha \lambda u ́ v \omega)$.

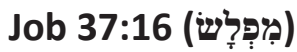

\begin{tabular}{|c|c|c|}
\hline MT & LXX & 11QtgJob \\
\hline 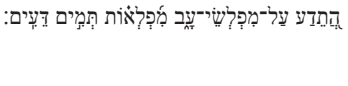 & 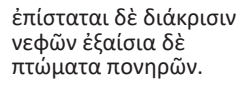 & עננה גבורה להלבש 11 אוא \\
\hline $\begin{array}{l}\text { Do you know the balancings of the } \\
\text { clouds, the wondrous works of the } \\
\text { one whose knowledge is perfect. }\end{array}$ & $\begin{array}{l}\text { And he understands } \\
\text { the division of the } \\
\text { clouds and the } \\
\text { extraordinary falls of } \\
\text { the wicked. }\end{array}$ & $\begin{array}{l}\text { [Do you kn]ow } \\
\text { how to clothe His } \\
\text { cloud with might? }\end{array}$ \\
\hline
\end{tabular}

The Hebrew hapax מִפְִ ha has been rendered by the lexeme

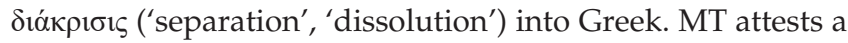
plural form whereas the LXX has a singular form. Only Greenspahn records this hapax as an absolute hapax (it is not present in Casanowicz's list and Lisowsky labels it as a non-absolute hapax). However, the meaning of the hapax can be derived from the root פלס ('to smooth', 'to level', 'to balance') (cfr. BDB 1979:814; Clines 2001:432). Therefore,

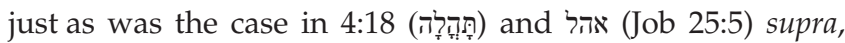


this absolute hapax cannot be labelled as such. It should rather be considered as a non-absolute hapax.

Dhorme (1967:568) had suggested that the LXX read פִפְּש as a form of פרש ('to make distinct', 'to divide'). This might be plausible because, as Cox argues (Cox forthcoming), the

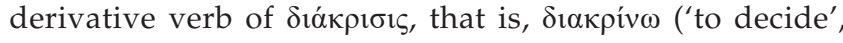
'to judge', 'to distinguish'), is also used in Leviticus 24:12 as a rendering of פרש. By doing so, LXX provided an adequate rendering of the Hebrew lexeme. Moreover, in 37:15, the LXX refers to the creation of light out of

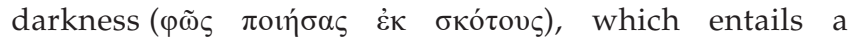
division (i.e. light vs. darkness). Thus, the choice of the

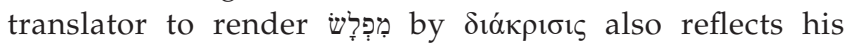
stylistic attention for the literary context.

\section{Conclusion}

Having analysed the Greek rendering of the Hebrew absolute hapax legomena in the speeches of Eliphaz, Bildad and Elihu in LXX Job, we can draw the following conclusions with regard to the translation technique of the LXX translator:

1. Most hapaxes have been rendered with an adequate Greek equivalent by the LXX translator. This is the case for

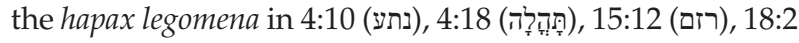

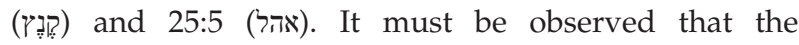
examination has indicated that three of the hapaxes, which were considered absolute at the outset of this study

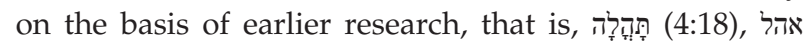
(25:5) a מִפְְרש (37:16), should actually be labelled nonabsolute hapax legomena, because our analysis indicated that their meaning might be derived from an existing Hebrew root.

2. Some Hebrew hapaxes have been rendered into Greek by drawing upon contextual exegesis, that is, (15:24),

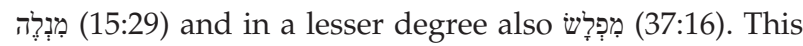
observation confirms the results of Verbeke on the Greek rendering of Hebrew hapax legomena in the speeches of Job and God. Therefore, it can indeed be considered a specific trait of the LXX translator of Job.

3. In one instance, the LXX does not provide a Greek rendering for the Hebrew hapax, that is, (33:24). Instead, he contrasted the image of flesh and bones in 33:21 and thereby enhanced its imagery.

4. In two cases, that is, (33:25), the LXX translator of Job probably had a Hebrew Vorlage that differed from the text attested in MT. In 33:20, the extant textual material does not allow any decision on whether the LXX translator paraphrased the Hebrew text or whether it rather had a diverging Vorlage.

These results point toward a translator who employed a variety of techniques to render possibly difficult Hebrew words. Although some of these words might have posed a challenge, the LXX translator never resorted to transliteration and has always aimed at providing an intelligible rendering of the Hebrew text, for example, by employing contextual exegesis.
This article has only examined the absolute Hebrew hapax legomena in the speeches of Job's friends. An examination of the non-absolute Hebrew hapax legomena in the same parts of LXX Job might shed even more light on its translation technique. Moreover, an analysis of the Greek rendering of Hebrew hapaxes in the prose sections in Job (prologue chapters 1-2 and epilogue 42:7-16) might also be worth examining in order to see whether the translator has rendered the prose sections differently than the poetic sections. Step by step, we are approaching a more nuanced and complete image on how the LXX translator rendered his Hebrew Vorlage into Greek.

\section{Acknowledgements}

The author would like to express his gratitude towards Johann Cook for inviting him to submit an article to the Special Collection of HTS. He also wants to thank the participants of the Groningen-Leuven-Oxford Network Conference 'Hebrew Bible and Jewish Antiquity' 08-09 March 2021, where this article was presented, for their remarks, as well as the anonymous reviewers. A last word of gratitude goes to his promotors, Prof. Dr Hans Ausloos (UCLouvain) and Prof. Dr Bénédicte Lemmelijn (KU Leuven) for their helpful suggestions.

\section{Competing interests}

The author declares that he has no financial or personal relationships that may have inappropriately influenced him in writing this article.

\section{Author's contributions}

B.B. is the sole author of this research article.

\section{Ethical considerations}

This article followed all ethical standards for research without direct contact with human or animal subjects.

\section{Funding information}

The financial and other assistance of the Fonds Special de Recherche (FSR) and the Institut de recherche Réligions, Spiritualités, Cultures, Sociétés (RSCS, UCLouvain) is acknowledged.

\section{Data availability}

Data sharing is not applicable to this article as no new data were created or analysed in this study.

\section{Disclaimer}

The views and opinions expressed in this article are those of the author and do not necessarily reflect the official policy or position of any affiliated agency of the author. 


\section{References}

Altschüller, M.A., 1886, 'Einige textkritische Bemerkungen zum Alten Testamente', ZAW 6(1), 211-213.

Ausloos, H., 2009, 'The Septuagint's rendering of Hebrew hapax legomena and the characterization of its "translation technique": The case of Exodus', Acta Patristica et Byzantina 20(1), 360-376. https://doi.org/10.1080/10226486.2009.12128801

Ausloos, H., 2013, 'Hapax legomena, the Septuagint, and Hebrew Lexicography', in M.K.H. Peters (ed.), XIV Congress of the International organization for Septuagint M.K.H. Peters (ed.), XIV Congress of the International organization for Septuagint
and cognate studies, Helsinki, 2010, pp. 291-300, SBLSCS 51, SBL, Atlanta, GA.

Ausloos, H. \& Lemmelijn, B., 2008, 'Rendering love: Hapax legomena and the characterisation of the translation technique of song of songs', in H. Ausloos, J. Cook, F. García Martínez, B. Lemmelijn \& M. Vervenne (eds.), Translating a translation: The LXX and its modern translations in the context of early Judaism, translation: The LXX and its modern trans

Ausloos, H. \& Lemmelijn, B., 2010, 'Content-related criteria in characterising the LXX translation technique,' in W. Kraus, M. Karrer \& M. Meiser (eds.), Die Septuaginta: Texte, Theologien und Einflüsse, pp. 356-376, WUNT 252, Mohr Siebeck, Tübingen.

Ausloos, H. \& Lemmelijn, B., 2012, 'Characterizing the LXX translation of Judges on the basis of content-related criteria: The Greek rendering of Hebrew absolute hapax legomena in Judge 3:12-30', in H. Ausloos, B. Lemmelijn \& J. Trebolle Barrera (eds.), After Qumran: Old and modern editions of the biblical texts - The historical books, pp. 171-192, BETL 246, Peeters, Leuven.

Ausloos, H., Lemmelijn, B. \& Kabergs, V., 2012, 'The study of aetiological wordplay as a content-related criterion in the characterization of LXX translation technique', in W. Kraus \& M. Karrer (eds.), Die Septuaginta: Entstehung, Sprache, Geschichte, 3. Internationale Fachtagung veranstaltet von Septuaginta Deutsch (LXX.D), Wuppertal 22.-25.7.2010, pp. 273-294, WUNT 286, Mohr Siebeck, Tübingen.

Baillet, M., Milik, J.T. \& De Vaux, R. (eds.), 1962, Les 'petites grottes' de Qumrân, DJD III, Clarendon Press, Oxford.

Beeckman, B., 2019, 'Proverbia de Animalibus: The Greek rendering of animal name in Proverbs', ZAW 131(2), 257-270. https://doi.org/10.1515/zaw-2019-2002

Beeckman, B., 2020, 'Unitas Vegetabilium? The Greek rendering of Hebrew floral, plant and herb names in LXX-Proverbs and LXX-Job', JSCS 53, 19-41.

Beer, G., 1897, Der Text des Buches Job, N. G. Elwertsche Verlagsbuchandlung, Marburg.

Brown, F., Driver, S.R. \& Briggs, C.A., 1979, The new Brown-Driver-Briggs - Genesius Hebrew and English Lexicon with an appendix containing the biblical aramaic, Hendrickson Publishers, Peabody, MA.

Casanowicz, I.M., 1904, 'Hapax Legomena. Biblical Data', The Jewish Encyclopedia 6 226-229.

Clines, D.J.A., 1993-2016, The dictionary of classical Hebrew volume I-IX, Sheffield Academic Press, Sheffield.

Cook, J. \& Van der Kooij, A., 2012, Law, Prophets, and wisdom: On the provenance of translators and their books in the Septuagint version, CBET 68, Peeters, Leuven.

Cox, C.E., 2007, 'Iob', in A. Pietersma \& B. G. Wright (eds.), A new English translation of the Septuagint: And the other Greek translations traditionally included under that title, pp. 667-696, Oxford University Press, New York, NY.

Cox, C.E., forthcoming, lob, s.n., s.l.

De Joode, J. 2018, Metaphorical landscapes and the theology of the book of Job: An analysis of Job's spatial metaphors, Brill, Leiden.

Dhorme, E., 1967, A commentary on the book of Job, Thomas Nelson \& Sons, London.

Elliger, K. \& Rudolph, W., 1977, Biblia Hebraica Stuttgartensia, 5th edn., Deutsche Bibelstiftung, Stuttgart.

García Martínez, F., Tigchelaar, E. \& Van der Woude, A. (eds.), 1998, Qumran cave 11 II. 11Q2-18, 11Q20-31, DJD XXIII, Clarendon Press, Oxford.

Genesius, W., 1921, Hebraïschen und Aramaïschen Handwörterbuch, 17th edn. Verlag von F. C. W. Vogel, Leipzig.

Gentry, P.J., 1995, The asterisked materials in the Greek Job, SBLSCS 38, Scholars Press, Atlanta, GA.

Gerleman, G., 1946, Studies in the Septuagint: I: The book of Job, LUA 43/2, Gleerup, Lund.
Greenspahn, F.E., 1984, Hapax Legomena in biblical Hebrew: A study of the phenomenon and its treatment since antiquity with special reference to verbal phenomenon and its treatment since antiquit
forms, SBLDS 74, Scholars Press, Chico, CA.

Hagedorn, U. \& Hagedoren, D., (eds.), 1984, Olympiodor, Diakon von Alexandria Kommentar zu lob, PTS 24, De Gruyter, Berlin.

Heater, H., 1982, A Septuagint translation technique in the book of Job, CBQMS 11 Catholic Biblical Association of America, Washington, DC.

Kabergs, V. \& Ausloos, H., 2012, 'Paronomasia or wordplay? A Babylonian confusion: Towards a definition of Hebrew Wordplay', Biblica 93(1), 1-20.

Koehler, L. \& Baumgartner, W., 1953, Lexicon in Veteris Testamenti Libros, Brill, Leiden.

Lemmelijn, B., 2008, 'Flora in Cantico Canticorum: Towards a more precise characterisation of translation technique in the LXX of song of songs', in A. Voitila \& J. Jokiranta (eds.), Scripture in transition: Essays on Septuagint, Hebrew Bible, and dead sea scrolls in honour of Raija Sollamo, pp. 27-51, SJS. Hebrew Bible, and
126, Brill, Leiden.

Lemmelijn, B., 2014, 'The Greek rendering of Hebrew hapax legomena in LXX Proverbs and Job: A clue to the question of a single translator?', in T. M. Law, K. De Troyer \& M. Liljeström (eds.), In the footsteps of Sherlock Holmes: Studies in the biblical text in honour of Anneli Aejmelaeus, pp. 133-150, CBET 72, Peeters, Leuven.

Liddell, H.G., Scott, R. \& Jones, H.S., 1996, A Greek-English Lexicon, 9th revised edn., Clarendon Press, Oxford.

Lisowsky, G., 1958, Konkordanz zum Hebräischen Alten Testament, Württembergische Bibelanstalt, Stuttgart.

Lust, J., Eynikel, E. \& Hauspie, K., 2015, Greek-English Lexicon of the Septuagint, 3rd corrected edn., Deutsche Bibelgesellschaft, Stuttgart.

Mangan, C., 1991, 'The Targum of Job', in C. Mangan, J.F. Healey \& P.S. Knobel (eds.), The Targum of Job, Proverbs, Qohelet, pp. 5-98, The Aramaic Bible 15, T\&T Clark, Edinburgh.

Milik, J.T., 1977, Qumrân grotte 4 II: Tefillin, Mezuzot et Targums (4Q128-4Q157), DJD VI, Clarendon Press, Oxford.

Montanari, F., 2015, The Brill dictionary of ancient Greek, Brill, Leiden.

Muraoka, T., 1991, 'Hebrew hapax legomena and Septuagint lexicography', in C. E. Cox (ed.), VII Congress of the International organization for Septuagint and cognate studies, Leuven, 1989, pp. 205-222, SBLSCS 31, Scholars Press, Atlanta, GA.

Muraoka, T., 2009, A Greek-English Lexicon of the Septuagint, Peeters, Leuven.

Puech, E., 2020, 'Le targum de Job de la grotte 4: 4Q157 = 4QtgJob', Revue de Qumran $32(1), 135-141$.

Schultens, A., 1737, Liber Jobi: cum nova versione ad Hebraeum fontem et commentario perpetuo, apud J. Lusac, Lugduni Batavorum.

Seow, C.-L., 2011, 'Putative hapax legomena in the book of Job', in J.F. Diehl \& M. Witte (eds.), Studien zur Hebräischen Bibel und ihrer Nachgeschichte. Beiträge der 32. Internationalen Ökumenischen Konferenz der Hebräischlehrenden, Frankfurt a.m. 2009, pp. 145-182, KUSATU 12.13, Hartmut Spenner, Kamen.

Seow, C.-L., 2013, Job 1-21: Interpretation and commentary, Illuminations, Eerdmans, Grand Rapids, MI.

Skehan, P.W., Ulrich, E. \& Sanderson, J.E. (eds.), 1992, Qumran Cave 4 IV. PaleoHebrew and Greek biblical manuscripts, DJD IX, Clarendon Press, Oxford.

Ulrich, E., Moore Cross, F., Fitsmyer, J.A., Flint, P.W., Metso, S., Murphy, C.M. et al. (eds.), 2000, Qumran cave 4 XI. Psalms to chronicles, DJD XVI, Clarendon Press, Oxford.

Van der Ploeg, J.P.M. \& Van der Woude, A.S. (eds.), 1971, Le Targum de Job de la grotte xi de Qumrân, Brill, Leiden.

Verbeke, E., 2008, 'The use of Hebrew hapax legomena in Septuagint studies: Preliminary remarks on methodology', in H. Ausloos, B. Lemmelijn \& M. Vervenne (eds.), Florilegium Lovaniense: Studies in Septuagint and trextual criticism in honour of Florentino García Martínez, pp. 507-521, BETL 224, Peeters, Leuven.

Verbeke, E., 2011, 'Hebrew hapax legomena and their Greek rendering in LXX Job', PhD thesis, Faculty of Theology and Religious Studies, KU Leuven (sup. B. Lemmelijn).

Ziegler, J., 1934, Der textkritische Wert der Septuaginta des Buches Job, pp. 277-296, Miscellaneis Biblicis II, Pontifico Instituto Biblico, Rome.

Ziegler, J., 1982, Job, Septuaginta. Vetus Testamentum Graecum. Auctoritate Academiae Scientiarum Gottingensis editum XI/4, Vandenhoeck \& Ruprecht, Göttingen. 